\title{
Assessment of Integrated Nutrient on Soil Properties and Yield of Cowpea (Vigna unguiculata L.)
}

\author{
Gavaskar*, Arun Alfred David, Tarence Thomas, Narendra Swaroop and Meraj Ahmed
}

\author{
Department of Soil Science and Agricultural Chemistry, Naini, Agricultural Institute, \\ Sam Higginbottom University of Agriculture, Technology and Sciences, \\ Prayagraj - 211 007, U. P., India, India \\ *Corresponding author
}

Keywords

Bio-fertilizers, Vermicompost, Rhizobium, Integrated nutrient, RDF, Cowpea, Yield attributes, Productivity, etc.

Article Info

Accepted: 26 July 2020 Available Online: 10 August 2020

\section{A B S T R A C T}

The present investigation was carried out at research farm, department of Soil Science and Agricultural Chemistry, Naini Agricultural Institute, SHUATS, Prayagraj (U.P.) during the Kharif season of 2019 with the objective to evaluate response of different levels of organic and inorganic fertilizers on soil health, growth and yield attributes of cowpea [Vigna unguiculata (L.)] Cv. Kashi Kanchan. The experiment was laid out in a Randomized Block Design with nine treatment combinations, i.e. N2V2, N1V2, N2V1, N1V1, N2R2, N1R2, N2R1, N1R1 and control. It was observed that for post-harvest, treatment $\mathrm{T} 9(100 \% \mathrm{RDF}+100 \%$ Rhizobium) was best in terms of growth, yield and economic parameters with maximum plant height $64.40 \mathrm{~cm}$, pods per plant 19.00, pod length 34.15 , seeds per pod 10.67 and total yield $164.13 \mathrm{q}$ ha-1. Treatment T9 (100\% RDF + $100 \%$ Rhizobium) was best in terms of economic parameters with maximum gross return of Rs. 1,64,130.00 and net profit was Rs. 1,10,240.00 with benefit-cost ratio 1: 3.05 .

\section{Introduction}

The advantage of combining organic and inorganic sources of nutrients in integrated nutrient management has been proved superior to the use of each component separately (Palaniappan and Annadurai,
2007). Rhizobium inoculation increased the root nodulation through better root development and more nutrient availability, resulting in vigorous plant growth and dry matter production which resulted in better flowering, fruiting and pod formation and ultimately there was beneficial effect on seed 
yield (Sardana et al., 2006). Vermicompost has been emerging as an important source in supplementing chemical fertilizer in agriculture in view of sustainable development after Rio Conference, vermicompost is a bio-fertilizer enriched with all beneficial soil microbes and also contains all the essential plant nutrients like N, P and $\mathrm{K}$. Since vermicompost helps in enhancing the activity of microorganisms in soil which further increase solubility of nutrients and their consequent availability to plants is known to be altered by microorganism by reducing soil $\mathrm{pH}$ at microsites, chelating action of organic acids produced by them and intraphyl mobility in the fungal filaments (Parthasarathi et al., 2008). Nutrient composition - Cowpea is loaded with various types of nutrients. It is rich in fiber, protein, iron, potassium, low in fat and calories. The cup of cowpea possesses $11.1 \mathrm{~g}$ fiber, $13.22 \mathrm{~g}$ protein, $35.5 \mathrm{~g}$ carbohydrate, $4.29 \mathrm{mg}$ iron, $475 \mathrm{mg}$ potassium, $0.91 \mathrm{~g}$ fat and 198 calories. Along with that, various amino acids such as $0.612 \mathrm{~g}$ of tryptophan, $0.41 \mathrm{~g}$ of histidine, $0.188 \mathrm{~g}$ of Methionine and $0.894 \mathrm{~g}$ of lysine is contained in this seed. The per capita availability of pulses in India is $35.5 \mathrm{~g}$ per day as against the minimum requirement of $70 \mathrm{~g}$ per day per capita as advocated by Indian Council of Medical Research. It is, therefore, imperative to increase the productivity of pulse crops especially those of minor importance (Anonymous, 2013-2014). About Variety - This is dwarf and bush type (height $50-60 \mathrm{~cm}$ ), photo-insensitive, early flowering (40-45 days after sowing) and early picking (50-55 days after sowing) variety suitable for growing in both spring-summer and rainy seasons. Pods are about $30-35 \mathrm{~cm}$ long, dark green, soft, fleshy and free from parchment. The cultivar gives green pod yield of about 150-175 q ha ${ }^{-1}$ and is resistant to golden mosaic virus and Pseudocercospora cruenta. This has been released and notified during the XIII meeting of Central Sub-Committee on Crop Standard Notification and Release of Varieties for Horticultural Crops for cultivation in U.P., Punjab, Bihar, Chhattisagarh, Orissa, A.P., M.P. and states. Area and Distribution Almost $33 \mathrm{~m} \mathrm{t}$ of dry cowpea grains are produced world over, of which Nigeria alone produces 2.1 million ton, followed by Niger $(0.65 \mathrm{~m} \mathrm{t})$ and Mali $(0.11 \mathrm{~m} \mathrm{t})$, making Nigeria therefore, World's single largest grower total global area of cowpea grown is almost $13.0 \mathrm{~m}$ ha, of the same nearly $93 \mathrm{~m}$ ha is grown in Africa only. In India cowpea is grown in almost $1.3 \mathrm{~m}$ ha particularly in Western, Central and penmsular regions in some of Indian states including Maharashtra, this crop is grown in all three seasons. The total world acreage under pulses is about 85.40 (M ha) with production of $87.40(\mathrm{Mt})$ at $1023 \mathrm{~kg} \mathrm{ha}^{-1}$ yields level. India, with $>29 \mathrm{M}$ ha pulses cultivation area, is the largest pulse producing country in the world. It ranks first in area and production with 34 per cent and 26 per cent respectively. During 2017-18 the country's productivity at $835 \mathrm{~kg} \mathrm{ha}^{-1}$, is a significant increase over Eleventh (662 kg ha $\left.{ }^{1}\right)$ and Twelfth plans $\left(745 \mathrm{~kg} \mathrm{ha}^{-1}\right)$. In India, total pulse area and production during 201718 has been $>293$ lakh hectares (L ha) and 245 lakh tonnes $(\mathrm{L} \mathrm{t})$ respectively. Out of the total area, >73 Lakh ha is in Madhya Pradesh alone, earning a prime status in pulse production commodity registering a remarkable $25 \%$ of the country's pulse area with 33\% production, thereby ranking first both in area and production. This is followed by Rajasthan in respect of area (16 per cent) and Maharashtra in case of total production (13 per cent). Compared to normal production, the estimated production during $2017-18$ is 30\% higher in case of total pulses, $32 \%$ gram, $27 \%$ arhar, $58 \%$ uradbean, $18 \%$ mungbean and $40 \%$ higher lentil production. More than 90 per cent of total pulse production has been the contribution of 10 states namely, Madhya Pradesh, Maharashtra, 
Rajasthan, Uttar Pradesh, Karnataka, Andhra Pradesh, Gujarat, Jharkhand, Tamil Nadu and Telangana.

\section{Material and Methods}

The experiment was conducted at the crop Research farm of the Soil Science and Agricultural Chemistry, Sam Higginbottom University of Agriculture, Technology and Sciences, Prayagraj, U.P. which is located on the south of the Prayagraj city. It is situated at 250o SW, 25024'23' $\mathrm{N}$ latitude and $81^{\circ}$ 50'38' E longitude and $98 \mathrm{~m}$ above the mean sea level. One control and eight nutrient management practices were used as a treatment with $3 \times 3$ Randomized block design having three different factors with level of $\mathrm{N}$ P K @ 50 and $100 \%$ kg ha-1, Level of Rhizobium @ 50 and $100 \%$ ha $^{-1}$, level of vermicompost @ 50 and $100 \% \mathrm{ha}^{-1}$ respectively. At the first amount of nutrient and N P K supplied by Rhizobium, Vermicompost, Urea, SSP and MOP respectively (Table 1 and 2). Scraping the crust of soils following by weeding was done three times at 20, 40 and 60 days after sowing. Irrigation was done as required by crop after sowing. Five plants were tagged from each plot for recording data. Row to row distance was maintained at $30 \mathrm{~cm}$ and plant to plant distance was $10 \mathrm{~cm}$, at the depth of $5 \mathrm{~cm}$ during the course of experiment, observations were recorded as mean values of the data.

\section{Pre- harvest observations}

Plant height $(\mathrm{cm})$ - Height of crop plants under different treatments was recorded at 20, 35 and 50 days interval. For this, five plants were randomly selected from each plot and tagged for observation to be recorded. Height of plants in $\mathrm{cm}$. recorded from ground level up to the base of the last fully opened leaf of the main shoot. No. of pods per plant - Total no. of pods per plant under different treatments were recorded at 50 days of crop maturity. For this, five plants were randomly selected from each plot and tagged for observation to be recorded.

\section{Post - harvest observations}

Pod Length $(\mathrm{cm})$ - Length of pod under different treatments was recorded at maturity of crop. For this, five plants were randomly selected from each plot and tagged for observation to be recorded. Length of pod in centimeter recorded from shoot tip to end point of pod. No. of seeds per pod - No. of seeds per pod under different treatments was recorded at crop maturity. For this, five plants were randomly selected from each plot and tagged for observation to be recorded. Pod yield $\left(\mathrm{q} \mathrm{ha} \mathrm{h}^{-1}\right)$ - The pod yield from the net plot area was recorded in $\mathrm{kg}$ plot $^{-1}$ and figure converted into $\mathrm{q} \mathrm{ha}^{-1}$.

\section{Dose of fertilizer}

1) $100 \% \mathrm{NPK}=(100 \% \mathrm{~N}: \mathrm{P}: \mathrm{K}=20: 60: 40$ $\mathrm{kg})$

2) $50 \% \mathrm{NPK}=(50 \% \mathrm{~N}: \mathrm{P}: \mathrm{K}=10: 30: 20$ $\mathrm{kg})$

3) $100 \%$ Rhizobium $=20 \mathrm{~g} \mathrm{~kg}^{-1}$ seed Rhizobium

4) $50 \%$ Rhizobium $=10 \mathrm{~g} \mathrm{~kg}^{-1}$ seed Rhizobium

5) $100 \%$ Vermicompost $=2 \mathrm{q} \mathrm{ha}^{-1}$ Vermicompost

6) $50 \%$ Vermicompost $=1 \mathrm{q} \mathrm{ha}{ }^{-1}$ Vermicompost

The tables show the interaction effects of $\mathrm{N} \mathrm{P}$ $\mathrm{K}$, Rhizobium, and Vermicompost are generally influenced growth and yield of cowpea. The statistically analyzed data presented in tables 3-7. The result of the data shows that plant height, no. of pod per plant, length of pod, no. of seed per pod, yield of cowpea. From the data presented in the treatment combination $\mathrm{T}_{9}-(100 \% \mathrm{RDF}+20 \mathrm{~g}$ 
$\mathrm{kg}^{-1}$ seed Rhizobium) was recorded maximum $64.40 \mathrm{~cm}$ plant height at 50 DAS. While it was recorded at par $43.63 \mathrm{~cm}$ at 50 DAS in treatment combination $\mathrm{T}_{1}-(\mathrm{Control})$. This may be due to application of major and minor nutrients, through different levels of organic manure and chemical fertilizers, increased the photosynthetic activity, chlorophyll formation, nitrogen metabolism and auxin contents in the plants which ultimately improving the plant height and no. of branches per plant.

\section{Plant height:}

The data presented in table 3 clearly shows the response of plant height of pea recorded at 20 DAS, 35 DAS and 50 DAS as influenced by different levels of N P K, Rhizobium and vermicompost. The plant height of cowpea was found to be increased significantly with the increase in levels of N P K, Rhizobium and vermicompost. The maximum plant height was recorded as $24.49 \mathrm{~cm}, 34.38 \mathrm{~cm}$ and $64.40 \mathrm{~cm}$ in $\mathrm{T}_{9}(100 \% \mathrm{RDF}+100 \%$ Rhizobium) at 20 DAS, 35 DAS and 50 DAS respectively and the plant height was recorded at par $10.30 \mathrm{~cm}, 18.63 \mathrm{~cm}$ and $43.63 \mathrm{~cm}$ in $T_{1}$ (control) at 20 DAS, 35 DAS and 50 DAS respectively. Increase in plant height due to increase in $\mathrm{N} P \mathrm{~K}$, Rhizobium and vermicompost may be due to adequate supply of nutrients which in turn helps in vigorous vegetative growth of plants and subsequently increase the plant through cell elongation, cell division, photosynthesis and turbidity of plant cell. The increase in nodulation and nitrogen fixation leads to more plant height. Similar findings were reported by Ashwani et al., (2016), Yadav et al., (2017), Abdel et al., (2012) and Maurya et al., (2017).

Table.1 Details of treatment of cowpea

Treatment

Dosage $\mathrm{ha}^{-1}$ in percentage

Symbol

Level of N, P \& K

$\begin{array}{ll}100 \% \text { NPK as SSP and MOP } & \mathrm{N}_{1} \\ 50 \% \text { NPK as SSP and MOP } & \mathrm{N}_{2}\end{array}$

Level of Rhizobium

100\% Rhizobium

$\mathrm{R}_{1}$

$50 \%$ Rhizobium

$\mathrm{R}_{2}$

Level of Vermicompost

100\% Vermicompost

$\mathrm{V}_{1}$

$50 \%$ Vermicompost

$\mathrm{V}_{2}$ 
Table. 2 Treatment combination of cowpea

\section{Symbol}

\section{Treatment Combination}
$\left(\mathrm{T}_{1}=\right.$ Control $)$
(Control)
$\left(\mathrm{T}_{2}=\mathrm{N}_{2}+\mathrm{V}_{2}\right)$
(@ $50 \% \mathrm{RDF}+1 \mathrm{q} \mathrm{ha}^{-1}$ Vermicompost)
$\left(\mathrm{T}_{3}=\mathrm{N}_{1}+\mathrm{V}_{2}\right)$
(@ $100 \%$ RDF + $1 \mathrm{q} \mathrm{ha}^{-1}$ Vermicompost)
$\left(\mathrm{T}_{4}=\mathrm{N}_{2}+\mathrm{V}_{1}\right)$
(@50\% RDF + $2 \mathrm{q} \mathrm{ha}^{-1}$ Vermicompost)
$\left(\mathrm{T}_{5}=\mathrm{N}_{1}+\mathrm{V}_{1}\right)$
(@ $100 \% \mathrm{RDF}+2 \mathrm{q} \mathrm{ha}^{-1}$ Vermicompost)
$\left(\mathrm{T}_{6}=\mathrm{N}_{2}+\mathrm{R}_{2}\right)$
(@50\% RDF + $10 \mathrm{~g} \mathrm{~kg}^{-1}$ seed Rhizobium)
$\left(\mathrm{T}_{7}=\mathrm{N}_{1}+\mathrm{R}_{2}\right)$
(@100\% RDF + $10 \mathrm{~g} \mathrm{~kg}^{-1}$ seed Rhizobium)
$\left(\mathrm{T}_{8}=\mathrm{N}_{2}+\mathrm{R}_{1}\right)$
(@50\% RDF + $20 \mathrm{~g} \mathrm{~kg}^{-1}$ seed Rhizobium)
$\left(\mathrm{T}_{9}=\mathrm{N}_{1}+\mathrm{R}_{1}\right)$
(@ $100 \% \mathrm{RDF}+20 \mathrm{~g} \mathrm{~kg}^{-1}$ seed Rhizobium)

Table.3 Effect of different levels of N P K, Rhizobium and vermicompost on the Plant height (cm) 20, 35 and 50 DAS of Cowpea

\begin{tabular}{|c|c|c|c|}
\hline \multirow{2}{*}{ Treatment } & \multicolumn{3}{|c|}{ Plant height (cm) } \\
\hline & $\mathbf{2 0} \mathbf{D A S}$ & $\mathbf{3 5} \mathbf{D A S}$ & $\mathbf{5 0} \mathbf{D A S}$ \\
\hline $\mathrm{T}_{1}$ & 10.30 & 18.63 & 43.63 \\
\hline $\mathrm{T}_{2}$ & 11.16 & 21.17 & 45.37 \\
\hline $\mathrm{T}_{3}$ & 13.37 & 23.38 & 47.79 \\
\hline $\mathrm{T}_{4}$ & 14.73 & 24.73 & 51.19 \\
\hline $\mathrm{T}_{5}$ & 16.37 & 26.37 & 53.71 \\
\hline $\mathrm{T}_{6}$ & 18.77 & 28.80 & 55.78 \\
\hline $\mathrm{T}_{7}$ & 20.53 & 30.56 & 58.07 \\
\hline $\mathrm{T}_{8}$ & 22.22 & 33.22 & 61.19 \\
\hline $\mathrm{T}_{9}$ & 24.49 & 34.38 & 64.40 \\
\hline $\mathrm{F}-$ test & $\mathrm{S}$ & $\mathrm{S}$ & $\mathrm{S}$ \\
\hline $\mathrm{SE} . \mathrm{d}( \pm)$ & 0.31 & 0.32 & 0.28 \\
\hline C.D. $(\mathrm{P}=0.05)$ & 0.67 & 0.69 & 0.58 \\
\hline
\end{tabular}


Table.4 Effect of different levels of N P K, Rhizobium and vermicompost on the number of pods $^{-1}$ plant at 50 DAS of Cowpea

\begin{tabular}{|c|c|}
\hline Treatment & Number of pods $^{-\mathbf{1}}$ plant \\
\hline $\mathbf{T}_{\mathbf{1}}$ & 9.33 \\
\hline $\mathbf{T}_{\mathbf{2}}$ & 10.42 \\
\hline $\mathbf{T}_{\mathbf{3}}$ & 12.00 \\
\hline $\mathbf{T}_{\mathbf{4}}$ & 13.30 \\
\hline $\mathbf{T}_{\mathbf{5}}$ & 14.47 \\
\hline $\mathbf{T}_{\mathbf{6}}$ & 15.53 \\
\hline $\mathbf{T}_{\mathbf{7}}$ & 16.70 \\
\hline $\mathbf{T}_{\mathbf{8}}$ & 17.80 \\
\hline $\mathbf{T}_{\mathbf{9}}$ & 19.00 \\
\hline F-test & $\mathrm{S}$ \\
\hline SE. $\mathbf{d}(\mathbf{(})$ & 0.12 \\
\hline C.D. $(\mathbf{P}=\mathbf{0 . 0 5})$ & 0.26 \\
\hline
\end{tabular}

Table.5 Effect of different level of N P K, Rhizobium and vermicompost on the pod length of Cowpea

\begin{tabular}{|c|c|}
\hline Treatment & Pod length $(\mathbf{c m})$ \\
\hline $\mathbf{T}_{\mathbf{1}}$ & 14.01 \\
\hline $\mathbf{T}_{\mathbf{2}}$ & 18.71 \\
\hline $\mathbf{T}_{\mathbf{3}}$ & 23.87 \\
\hline $\mathbf{T}_{\mathbf{4}}$ & 19.97 \\
\hline $\mathbf{T}_{\mathbf{5}}$ & 21.80 \\
\hline $\mathbf{T}_{\mathbf{6}}$ & 26.77 \\
\hline $\mathbf{T}_{\mathbf{7}}$ & 21.70 \\
\hline $\mathbf{T}_{\mathbf{8}}$ & 27.67 \\
\hline $\mathbf{T}_{\mathbf{9}}$ & 34.15 \\
\hline $\mathbf{F}-\mathbf{t e s t}$ & $\mathbf{S}$ \\
\hline SE. $\mathbf{d}(\mathbf{\pm})$ & 1.06 \\
\hline C.D. $(\mathbf{P}=\mathbf{0 . 0 5})$ & 2.25 \\
\hline
\end{tabular}


Table.6 Effect of different level of N P K, Rhizobium and vermicompost on the seeds $\operatorname{pod}^{-1}$ of cowpea

\begin{tabular}{|c|c|}
\hline Treatment & Seeds per pod \\
\hline $\mathbf{T}_{\mathbf{1}}$ & 6.00 \\
\hline $\mathbf{T}_{\mathbf{2}}$ & 6.67 \\
\hline $\mathbf{T}_{\mathbf{3}}$ & 7.67 \\
\hline $\mathbf{T}_{\mathbf{4}}$ & 6.67 \\
\hline $\mathbf{T}_{\mathbf{5}}$ & 8.67 \\
\hline $\mathbf{T}_{\mathbf{6}}$ & 9.67 \\
\hline $\mathbf{T}_{\mathbf{7}}$ & 7.67 \\
\hline $\mathbf{T}_{\mathbf{8}}$ & 10.00 \\
\hline $\mathbf{T}_{\mathbf{9}}$ & 10.67 \\
\hline $\mathbf{F}-\mathbf{t e s t}$ & $\mathrm{S}$ \\
\hline SE. $\mathbf{d}(\mathbf{(})$ & 0.84 \\
\hline C.D. $(\mathbf{P}=\mathbf{0 . 0 5})$ & 1.77 \\
\hline
\end{tabular}

Table.7 Effect of different level of N P K, Rhizobium and vermicompost on the yield of Cowpea

\begin{tabular}{|c|c|}
\hline Treatment & yield $\left(\mathbf{q} \mathbf{h a}^{-\mathbf{1}}\right)$ \\
\hline $\mathrm{T}_{1}$ & 132.33 \\
\hline $\mathrm{T}_{2}$ & 146.00 \\
\hline $\mathrm{T}_{3}$ & 153.33 \\
\hline $\mathrm{T}_{4}$ & 138.33 \\
\hline $\mathrm{T}_{5}$ & 144.17 \\
\hline $\mathrm{T}_{6}$ & 154.20 \\
\hline $\mathrm{T}_{7}$ & 156.27 \\
\hline $\mathrm{T}_{8}$ & 159.07 \\
\hline $\mathrm{T}_{9}$ & 164.13 \\
\hline F-test & $\mathrm{S}$ \\
\hline SE. $\mathrm{d}( \pm)$ & 1.32 \\
\hline C.D. $(\mathrm{P}=0.05)$ & 2.80 \\
\hline
\end{tabular}




\section{Pods per plant}

The data presented clearly shows the response of pods per plant of cowpea recorded at 50 DAS as influenced by different levels N P K, Rhizobium and vermicompost. The number of pods per plant of cowpea was found to be increased significantly with the increase in levels of N P K, Rhizobium and vermicompost. The maximum number of pods was recorded as 19.00 in $\mathrm{T}_{9}(100 \%$ $\mathrm{RDF}+100 \%$ Rhizobium) at $50 \mathrm{DAS}$ and the number of leaves were recorded at par 9.33 in $\mathrm{T}_{1}$ (control) at 50 DAS. Increase in number of pods may be due to adequate nutrients supply which enhanced the vegetative growth of plant and subsequently the number of pods. Similar findings were reported by Ashwani et al., (2016), Yadav et al., (2017), Abdel et al., (2012) and Maurya et al., (2017).

\section{Pod length}

The data presented clearly shows the response of pod length of cowpea recorded as influenced by different levels $\mathrm{N} P \mathrm{~K}$, Rhizobium and vermicompost. The pod length per plant of cowpea was found to be increased significantly with the increase in levels of N P $\mathrm{K}$, Rhizobium and vermicompost. The maximum pod length was recorded as 34.15 in $\mathrm{T}_{9}(100 \% \mathrm{RDF}+100 \%$ Rhizobium $)$ and the pod length was recorded at par 14.01 in $\mathrm{T}_{1}$ (control). Increased in pod length may be due to adequate availability of nutrients during reproductive stage of crop results in the increased pod length. Similar results were also reported by Ashwani et al., (2016), Yadav et al., (2017), Abdel et al., (2012) and Maurya et al., (2017).

\section{Seeds per pod}

The data presented clearly shows the response of seeds per pod of cowpea recorded as influenced by different levels $\mathrm{N} P \mathrm{~K}$,
Rhizobium and vermicompost. The number of seeds per pods of cowpea was found to be increased significantly with the increase in levels of N P K, Rhizobium and vermicompost. The maximum number of seeds per pods was recorded as 10.67 in $\mathrm{T}_{9}$ (100\% RDF+ $100 \%$ Rhizobium) and the number of seeds per pods were recorded at par 6.00 in $\mathrm{T}_{1}$ (control). Increase in number of seeds per pod may be due to adequate availability of nutrients during reproductive stage of crop results in the formation of more seeds. Similar results were also reported by Ashwani et al., (2016), Yadav et al., (2017), Abdel et al., (2012) and Maurya et al., (2017).

\section{Pod yield}

The data presented clearly shows the response of pod yield of cowpea recorded as influenced by different levels N P K, Rhizobium and vermicompost. The pod yield of cowpea was found to be increased significantly with the increase in levels of N P K, Rhizobium and vermicompost. The maximum pod yield was recorded as 164.13 in $\mathrm{T}_{9}(100 \% \mathrm{RDF}+100 \%$ Rhizobium) and the pod yield was recorded at par 132.33 in $\mathrm{T}_{1}$ (control). Increase in pod yield may be due to adequate availability of nutrients during reproductive stage of crop results in the formation of more pods. Similar results were also reported by Ashwani et al., (2016), Yadav et al., (2017), Abdel et al., (2012) and Maurya et al., (2017)

\section{Summary}

Application of $100 \%$ RDF +20 g $\quad$ kg-1 significantly enhanced the plant height and number of branches per plant at harvest. Significantly higher number of pods per plant number of seed per pod, seed, straw and biological yield. Each successive dose of N P $\mathrm{K}$, Rhizobium and Vermicompost, resulted in a significant increase in all growth parameters i.e. plant height, number of leaves, number of 
branches and dry mater accumulation. Maximum growth and dry matter accumulation was recorded at N20 P60 K40 applied as Urea, SSP and MOP + $20 \mathrm{~g} \mathrm{kg-1}$ seed Rhizobium. Interactive effect of biofertilizer and fertility levels significantly influenced seed yields, $\mathrm{N}$ and $\mathrm{P}$ uptake by seed and net returns and maximum being with $100 \%$ RDF+20 g kg-1 seed Rhizobium. Application of $100 \% \mathrm{RDF}+20 \mathrm{~g} \mathrm{~kg}-1$ seed Rhizobium significantly increased the organic carbon, available N, P2O5 and $\mathrm{K} 2 \mathrm{O}$ content in soil. But the maximum available $\mathrm{N}, \mathrm{P}, \mathrm{K}$ and O.C. \% in soil was recorded at N20 P60 $\mathrm{K} 40+20 \mathrm{~g} \mathrm{~kg}-1$ seed Rhizobium. Maximum net return by seed and straw yield was obtained significantly with Rhizobium + N20 P40 K60.

\section{Conclusion}

The highest seed yield and plant growth is obtained from T9= N1+R1 (@ 100 \% RDF +20 g kg-1 seed Rhizobium) treatment. It is also found that Rhizobium and Vermicompost are effectively gave good result comparison to other treatment and control treatment. The treatment $\mathrm{T}_{9} \mathrm{f}=\mathrm{N} 1+\mathrm{R} 1$ showed a highest benefit-cost ratio followed by $\mathrm{T}_{8}=\left(\mathrm{N}_{2}+\mathrm{R}_{1}\right)$ other treatments so use of Rhizobium and vermicompost is the recommended to the farmers and use of bio-fertilizers like Rhizobium and manures like vermicompost should be increase.

\section{Acknowledgement}

The author is thankful to Hon'ble Vicechancellor, HOD, Advisor and non-teaching staff of Department of Soil Science and Agricultural Chemistry, Sam Higginbottom University Agriculture, Technology and Sciences, Prayagraj, U.P. for providing all facilities to clarify my studies.

\section{References}

AbdeI-SaIam, M. A. and Salem, H. M. (2012). Interaction Between Potassium and Organic Manure Application on Growth of Cowpea (Vigna unguiculata L.) and soil properties in newly reclaimed sandy soil. World Journal of Agricultural Sciences, 8 (2): 141-149.

Ashwani, K. and Pandita, V. K. (2016). Effect of integrated nutrient management on seed yield and quality in cowpea. Legume Research - An International Journal, 39 (3): 448-452.

Chauhan, D.K., Umrao, R., Bijalwan, A., (2016). Effect of NPK levels in combination with Rhizobium and PSB culture on growth and yield of greengram (Vigna radiata $L$. Wilczek) under Subabul (Leucaena leucocephala) based agro-forestry systems. Int. J. Curr. Res. Biosci. Plant Biol.,3 (2): 54-57.

Khajuria, S, Thomas, T. and Kumar, V. (2014). Effect of biofertilizer and different sources of phosphatic fertilizers in soil properties, nutrient uptake and yield of field pea (Pisum sativum L.) in alluvial soil. Environment and Ecology, 32 (4) 17201724.

Maurya, S. K., Gupta, S., Singh, D. P. and Kasera, S. (2017). Effect of integrated nutrient management on growth and yield attributes of table pea (Pisum sativum L.) cv. AP-3. International Journal of Chemical Studies; 5 (6): 906-908.

Panda S.C. (2012) Handbook of agriculture; 310321.

Panda, R. R., Sahu, G. S., Dash, S. R., Muduli, K. C., Nahak, S., Pradhan, S. R. and Mangaraj, S. (2017). Integrated nutrient management for seed production in cowpea [Vigna unguiculata L.], Journal of Pharmacognosy and Phytochemistry, 6 (5): 1845-1849.

Singh, B. and Pareek, R.G. 2003. Effect of phosphorus and bio-fertilizers on growth and yield of mungbean. Indian Journal of Pulses Research, 16: 31-33.

Singh, H. and Reddy, M.S. 2011. Efficiency of inoculation with phosphate solubilizing fungus on growth and nutrient uptake of wheat and maize plants fertilized with rock 
phosphate in alkaline soils. European Journal of Soil Biology, 47: 30-34.

Singh, S. and Kapoor, K.K. 1992. Effect of inoculation of phosphorus solubilizing micro- organisms and an arboscular mycorrhizal fungus on mungbean grown under natural soil conditions Mycorhiza, 7: 249-253.

Singh, S.R., Bhat, M.L., Wani, J.A. and Najar, G.R. 2009. Role of Rhizobium and VAM fungi for improvement in fertility and yield of green gram under temperate conditions. Journal of the Indian Society of Soil Science, 57: 45-52.

Snell, F.D. and Snell, C.T. 1949. Calorimetric Methods of Analysis, Third Edn. Vol, II D. Van Nostrand Co. Inc., New York. Soil Survey Staff, 1975. Soil Taxonomy. Agriculture Hand Book No. 16

Subbiah, B.V. and Asija, G.L. 1956. A rapid procedure for the determination of available nitrogen in soils. Current Science, 25: 259260.

Thenua, O.V.S., Singh, S.P. and Shivakumar, B. G. 2010. Productivity and economic of chickpea (Cicer arietinum) fodder sorghum (Sorghum bicolour) cropping system as influenced by $\mathrm{P}$ sources, bio-fertilizer to chickpea. Indian Journal of Agronomy, 55:22-27.

Tilak, K.V.B.R and Annapurna, K. 1993. Effect of PSB in different crop. India National Academic Science, 59: 315-324.

Tiwari, D. and Kumar, K. 2009. Effect of biofertilizer and phosphorus levels on growth, nodulation and yield of mungbean. (In) International Conference on Grain Legumes : Quality Improvement, Value Addition and Trade held during 14-16 February, 2009 at Indian Institute of Pulses Research, Kanpur.
Umale, S.M., Thosar, V.R., Chorey, A.B. and Chimate, A.N. 2002. Growth response of soybean to $\mathrm{P}$ solubilizing bacteria and phosphorus level. Journal of Soils and Crops, 12: 258-261.

USDA : 436. Srinivasa Reddy, K. and Uma Mahesh, P. 1995. Proceedings of National Seminar on Development of Soil Science, pp. 114.

Vaisya, V.K.; Gayendregdkar, G.R. and Penday, R.L. 1983. Effect of Rhizobium inoculation on nodulation and grain yield of mungbean. Indian Journal of Microbiology, 23: 228230.

Vasanthi, D. and Kumarswamy, K. 1999. Effect of continuous cropping and fertilization on chemical properties of soil. Journal of the Indian Society of Soil Science, 37: 171-173.

Vasanthi, D. and Subramanian, S. 2004. Effect of vermicompost on nutrient uptake and protein content in blackgram. Legume Research, 27: 293-295.

Vikram, A. and Hamzehzarghani, H. 2008. Effect of phosphate solubilizing bacteria on nodulation and growth parameters of greengram (Vigna radiata L. Wilczek). Research Journal of Microbiology, 3: 6272.

Wakley, A. and Black, I. A. (1947) Critical examination of rapid method for determining organic carbon in soils, effect of variance in digestion conditions and of inorganic soil constituents. Soil science.632:251.

Yadav, A. K., Naleeni, R. and Singh D. (2017). Effect of organic manures and biofertilizers on growth and yield, International Journal of Chemical Studies, 5 (6): 906-908.

\section{How to cite this article:}

Gavaskar, Arun Alfred David, Tarence Thomas and Narendra Swaroop and Meraj Ahmed. 2020. Assessment of Integrated Nutrient on Soil Properties and Yield of Cowpea (Vigna unguiculata L.). Int.J.Curr.Microbiol.App.Sci. 9(08): 3484-3493. doi: https://doi.org/10.20546/ijcmas.2020.908.403 